Original Research Paper

\title{
A Typology to Describe School Choice Policy in the United States: Using Cluster Analysis to Categorize States' Charter School Law Characteristics
}

\author{
${ }^{1}$ William Dabney, ${ }^{2}$ Bret Blackmon and ${ }^{3}$ Michelle M. Livermore \\ ${ }^{1}$ Department of Social Work, Carlow University, USA \\ ${ }^{2}$ Department of Social Work, The University of Southern Mississippi, USA \\ ${ }^{3}$ Department of Social Work, Louisiana State University, USA
}

\author{
Article history \\ Received: 17-12-2020 \\ Revised: 07-04-2021 \\ Accepted: 17-04-2021 \\ Corresponding Author: \\ Bret Blackmon \\ Department of Social Work, \\ The University of Southern \\ Mississippi, USA \\ Email: bret.blackmon@usm.edu
}

\begin{abstract}
Persistent educational inequality in the United States has inspired various school reform efforts with states adopting a wide variety of charter school laws. This study developed a typology of state-level charter school laws. U.S. states $(\mathrm{N}=50)$ were described and categorized based on characteristics of their charter school laws related to autonomy, funding equity and growth. Autonomy referred to independence from state and local authorities and in teacher hiring decisions, while funding equity included student funding as well as funding for facilities. Charter school growth referred to the state's ability to initiate and authorize charter schools including lack of cap on the number of charter schools permitted and the existence of an appeal process and multiple charter authorizers. A cluster analysis produced three types of state classifications based on charter school laws that were unique regarding charter school autonomy, funding equity and growth. Support-with-limited-growth states had charter school laws that were supportive of autonomy and funding equity, but not growth. Laws in limited-support states were not supportive of autonomy, funding equity, or growth at high rates. The final type of state, all-supportive, had charter school laws that generally supported provisions in the law that promote autonomy, funding equity and growth. ANOVA and chi-square tests demonstrated significant differences among the state clusters. Results revealed a state charter law typology that can help policy makers and researchers understand and evaluate these changes.
\end{abstract}

Keywords: Charter School, Charter Legislation, Charter Laws, School Choice

\section{Introduction}

Educational inequality based on race, ethnicity and income persist as major problems in the U.S. (Jacob and Ludwig, 2008). Disadvantaged children are at higher risk for an array of negative educational outcomes. Approximately $22 \%$ of fourth grade students eligible for free lunch score at proficient levels in reading compared with $52 \%$ of those whose family incomes do not qualify for free lunch (NCES, 2017b). The disparity is even more pronounced regarding math scores where only $25 \%$ of free lunch eligible fourth graders meet proficiency levels compared to $57 \%$ of those from wealthier families (NCES, 2017a). Regarding race and ethnicity, substantial disparities in achievement test scores between whites and minority groups can be observed as early as age three (Neal and Schanzenbach, 2008).
Over the past two decades, many states passed school choice legislation to address educational inequality. School choice allows parents to decide where to enroll their children, thereby introducing market competition into the education system to address the perceived failure of traditional public schools (Henig, 2008). The most popular type of school choice legislation has been the creation of charter schools. Charters schools have promoted autonomy in decision making on school structure, standards and culture, but are held accountable for many of the same measures (i.e., standardized testing) as traditional public schools (Buddin and Zimmer, 2005). Unlike traditional public schools, a student's residential address does not dictate charter school attendance (Buddin and Zimmer, 2005). 
Research on the relative effectiveness of charter schools is mixed. Some studies reveal better outcomes in traditional public-school system while others illustrate more success in charters schools (Bettinger, 2005; Cohodes, 2016; Eberts and Hollenbeck, 2002; Gronberg and Jansen, 2001; Hanushek et al., 2002; Ni and Rorrer, 2012; Solmon et al., 2001). However, no conclusive evidence has settled the debate between the effectiveness of charter schools and traditional public schools (Berends, 2015).

The current study examines three aspects of charter school laws that comprise part of the external policy environment experienced by schools in different states. These characteristics include school autonomy, funding and growth. Charter school autonomy refers to the amount of control that state education boards and school districts have over charter school operations and hiring practices. Funding equity refers to the whether funding per pupil and facility funding in charter schools and traditional public schools are equal. Growth includes the state's ability to cap the number of charter schools and how states initiate or authorize new charters. The purpose of this study is to describe variations among U.S. states in charter school laws and to categorize states into statistically unique clusters based on differences in charter school laws. Findings provide a policy-informed framework to help future researchers account for policy differences that may affect charter school adoption and student outcomes.

\section{Literature Review}

\section{Charter Schools}

Charter schools exhibit features of both a public and private schools. While they receive public funds, private for-profit or non-profit entities operate them and employ faculty and staff (Henig, 2008). They receive public money on a per-pupil basis and cannot charge tuition, but they can acquire additional funding from outside sources. While government entities exert some control over these schools, school boards do not directly control them (Henig, 2008). Instead, local school boards and/or state-level institutions grant charters to school operators that allow various levels of autonomy regarding leadership structure, curricula, teacher qualifications, enrollment practices and other operational characteristics (Henig, 2008). School charters describe charter school operations and the charter-granting entities enable charter schools to continue business as long as they meet the standards specified in the charter (Henig, 2008).

State governments can enable governmental entities such as state departments of education and local school boards the right to grant charters. Yet, these charter- granting entities vary substantially across states. In some states, the local school district solely approves charters, while decision-making in other states involves several bureaucratic institutions (Henig, 2008).

\section{Charter School Adoption}

Between 2004 and 2014, the total number of charter schools in the U.S. increased from 3,400 to 6,750. Charter school student enrollment also increased over the last decade. From 2004-2014, the percentage of public charter schools with 300 or more students increased, whereas those with fewer than 300 students decreased (USDE, 2014). During that same decade, students enrolled in public charter schools increased from 0.9 million to 2.7 million, while student numbers in traditional public schools decreased by 0.4 million (USDE, 2014).

School choice policy adoption has been addressed in the literature using event history analysis to model trends (Cohen-Vogel and Ingle, 2007; Renzulli and Roscigno, 2005; Wong and Langevin, 2007). Renzulli and Roscigno (2005) found that states tended to copy adjacent states in adopting charter school laws and revealed regional similarities in the creation of charter schools. Findings also revealed state-specific factors associated with charter school adoption such as the strengths of teacher unions, urbanization, Republican Party dominance, the competition between the private and public school sectors. Another study found political and economic factors that predicted the likelihood of states authorizing new charter schools. Factors included Republican partisan gubernatorial control, more private schools, more educational finance litigation, more minority representation of students and lower spending per classroom (Wong and Langevin, 2007). Cohen-Vogel and Ingle (2007) investigated the influence of the charter school policy-making process and how that process influenced neighboring states. Findings indicated that neighboring state legislatures were most influenced during the agenda setting and proposal formulation stages of the process and were least influenced during the actual policy adoption stage.

\section{Charter School Effectiveness}

Research has also shown mixed results on charter school effectiveness (Lubienski, 2003). In studies conducted in Arizona, Texas and Utah, researchers found that charter schools initially perform worse than traditional public schools in student achievement (Solmon et al., 2001; Gronberg and Jansen, 2001; Ni and Rorrer, 2012). After two to three years, however, student achievement begins to equal that of their traditional public school peers (Solmon et al., 2001; Gronberg and Jansen, 
2001; Ni and Rorrer, 2012). A more recent study indicated positive trends for charter schools using a longitudinal research design that compared charter schools to district schools from 2005-2017 (Shakeel and Peterson, 2020). Findings showed greater gains in reading and math for the charter school students with the greatest gains among African Americans and students of low socioeconomic status.

Research on school performance has also been mixed depending on the state where the research was conducted. Studies in Texas and in Michigan showed that charter schools performed worse than or equal to their traditional public school counterparts in standardized test scores (Hanushek et al., 2002; Eberts and Hollenbeck, 2002; Bettinger, 2005). Conversely, a Boston, MA study showed higher test scores among the charter schools than traditional public schools (Cohodes, 2016).

Regarding charter schools designed for at-risk children, another Texas-based study indicated that the atrisk charter schools outperformed traditional public schools with similar populations (Gronberg and Jansen, 2001). This study also indicated that the charter schools focusing on at-risk children saw the largest test score gains when compared to other charter schools and traditional public schools with lower-risk populations (Gronberg and Jansen, 2001).

\section{Research Gaps}

Much of the research masks the vast differences in state-level charter school laws by treating charter school adoption as a dichotomous variable at the state level (Mintrom and Vergari, 1998; Renzulli and Roscigno, 2005; Wong and Langevin, 2007; Cohen-Vogel and Ingle, 2007). Prior studies have only modeled the likelihood of a state adopting charter school legislation rather examining the particular characteristics of the law. Regarding charter school effectiveness, the majority of studies used the school as the unit of analysis and compared schools within one state (Solmon et al., 2001; Gronberg and Jansen, 2001; Hanushek et al., 2002; Eberts and Hollenbeck, 2002; Bettinger, 2005; $\mathrm{Ni}$ and Rorrer, 2012; Cohodes, 2016). Until now, research has not provided a nuanced framework from which to examine state variations in charter school laws, limiting the ability to study cross-state charter school performance.

\section{Study Objective}

Charter school legislation at the state government level has become the norm in U.S. education policy. Therefore, researchers should develop a nuanced understanding of how school-choice policy varies among states. This study builds on previous research by providing a typology of charter school laws to help researchers account for the impact of state-level policy variations. The first objective is to categorize U.S. states into clusters based upon their charter school legislation characteristics such as autonomy, funding equity and growth. Secondly, the authors will examine differences across each cluster by comparing the composite variables of state autonomy, local/district autonomy, teacher hiring autonomy, student funding, facility funding, no cap on growth, appeals processes allowed and multiple authorizers allowed. These variables are clarified in the measures section.

\section{Methods}

Administrative data from the Center for Education Reform (CER) for 2013-2014 academic year were used for this study. The data contained content on charter school law characteristics for each state and were accessed publicly through the Center for Education Reform's website. Data collected in the areas of charter school autonomy, funding equity and charter school growth were converted into an IBM SPSS data file for analysis.

The (Washington, 2014) mission is to, "expand educational opportunities that lead to improved economic outcomes for all Americans, particularly our youth, ensuring that the conditions are ripe for innovation, freedom and flexibility throughout U.S. education." The Center supports charter school proliferation and other school choice legislation. Although the Center has clear biases, they collect data related to charter school legislation on each U.S. state. The data used in this study reflect only the presence or absence of state law characteristics and are not based on value judgement. As such, these data are appropriate for objective scientific study.

\section{Study Population}

U.S. state comprise the units of analysis for the current study. In 2014, 42 states had passed charter school legislation, while six states had not. Table 1 contains a list of states in both categories.

Table 1: States that have adopted charter school laws since 2014

\begin{tabular}{ll}
\hline Adopted & AK, AR, AZ, CA, CO, CT, DE, FL, GA, HI, IA, ID, IL, IN, KS, LA, MA, MD, ME, MI, MN, MO, \\
& MS, NC, NH, NJ, NM, NC, NY, OH, OK, OR, PA, RI, SC, TN, TX, UT, VA, WA, WI and WY, \\
Have not adopted & AL, MT, NB, ND, SD, VT, WV and KY \\
\hline
\end{tabular}

Note: The cut-off 2014 is used because a majority of published data regarding charter school legislation is update through 2014 


\section{Measures}

The authors used binary coding to indicate the presence or absence of a condition describing elements of charter school laws in each state. Although CER provides state ratings that may contain bias, the authors crossreferenced the CER information with state legislative data. Composite variables were coded 1 to indicate the presence of a condition and coded 0 to indicate the condition's absence. The sums of sets of composite variables created three index variables: Charter school autonomy, funding equity and charter school growth.

Charter School Autonomy. The autonomy index indicated the extent of state and local government control over charter school operations in each state. Each composite variable was coded 1 to indicate the presence of autonomy and coded 0 to indicate its absence. The charter school autonomy composite variables included state autonomy, local/district autonomy and teacher hiring autonomy. State autonomy represented charter schools' autonomy from state laws that govern the operation of traditional public schools. Local/district autonomy represented charter schools' autonomy from local school boards and school districts. This composite variable indicated whether charter schools must follow local school board rules that oversee operations of traditional public schools. Teacher hiring autonomy indicated that a state allowed charter schools autonomy in hiring and firing of employees, allowing union participation and did not require them to adhere to state employment standards for their teachers. The composite variables that made up the charter school autonomy index were combined to produce a school autonomy score for each state.

Charter School Funding Equity. The charter school funding equity index addressed whether charter schools received the same amount of money as traditional public schools. Funds may be allocated by the state, the district, or both and, typically, are allotted for each student that attends the school. This can also include equal funds provided for charter school facilities and traditional public schools. States can fund charter school organizations through grants, capital outlays, or loans. On the other hand, states can choose not to provide charter schools with avenues to secure funding for facilities. The composite variables for charter school funding equity index were combined to produce a score for each state. The charter school funding equity index composite variables included (1) student funding and (2) facility funding.

Student funding indicated whether charter schools received the same per pupil funding as traditional public schools in the same state. Facility funding indicated whether or not charter schools received extra state funds for items such as building maintenance, technology and additional grounds keeping.

Charter School Growth. The charter school growth index indicated a state's ability to initiate and authorize charter schools. It included whether a state had a yearly cap on charter schools, allowed an appeals process if their charter was rejected and allowed multiple entities to authorize charter schools (i.e., multiple authorizers). Each composite variable was coded 1 or 0 to indicate the presence or absence of a condition. No cap, appeal process allowed and multiple authorizers allowed comprised the composite variables that made up the charter school growth index.

The no cap on charter schools composite variable indicated whether there was a cap imposed by state government on the number of charter schools that could be authorized in one year. Appeal process indicated whether the state government allowed an appeals process for charter schools whose application was denied. Multiple authorizers indicated whether there were multiple entities that could authorize charter schools within a state such as state government, school districts, or local school boards.

\section{Analysis Plan}

In the first analysis, the authors used a hierarchical cluster analysis to categorize states based on their charter school law characteristics. Cluster analysis classifies multivariate data into subgroups and reveals the characteristics of any patterns (Everitt et al., 2011). This analysis used a top-down hierarchical clustering algorithm. This approach began with all states in one cluster and then iteratively separated them into more clusters with fewer states that were most similar to them on the measured dimensions of charter school laws.

Analysis Of Variance (ANOVA) statistics were used to determine if state clusters differed significantly on each policy provision. The authors computed mean cluster scores for the composite variables of state autonomy, local/district autonomy, teacher hiring autonomy, student funding, facility funding, no cap on growth, appeals process allowed and multiple authorizers allowed. Chisquare tests examined differences among the composite variables across the three clusters.

\section{Results}

For the autonomy composite variable, descriptive findings indicated that the most states had complete autonomy at the state and district/local level and in teacher hiring (Table 2). Thirty-three states (67.7\%) had laws providing charter schools with complete autonomy at the state level, while thirty-four states $(68.6 \%)$ provided complete autonomy at the local/district level. There were 28 states $(56.9 \%)$ that provided charter schools with complete autonomy in hiring teachers.

The descriptive findings for charter school funding equity was mixed among the states (Table 2). Thirteen $(27.5 \%)$ states shared the same formula funding as public schools, whereas 29 states $(58.8 \%)$ had the same facility funding as public schools.

Findings regarding the charter school growth variable indicated the presences of these laws in approximately half the states. Twenty-five states $(50 \%)$ had no cap on the 
number of charter schools that could be authorized annually. Twenty-four states (49\%) allowed an appeals process for charters that had been denied by the state or local government. Twenty-five states (50\%) allowed multiple authorizers to authorize charter schools in the state.

The authors conducted a top-down hierarchical cluster analysis to categorize states according to their charter school law characteristics. After considering numerous clustering solutions, three distinct groups of states emerged from the most robust analysis. A two-cluster solution was too broad and the four-cluster solution mimicked the three cluster with adding only Rhode Island. This solution was not appropriate because a cluster with only one state would limit the ability to run significance tests on state law differences. A dendrogram illustrating the cluster solutions is presented in Fig. 1.

Descriptive statistics revealed a number of distinguishing features of each cluster, which can be found in Fig. 2. Cluster 2 included the eight states that had not adopted any charter school legislation and six other states (KS, VA, IA, MD, AK and RI) that had adopted charter laws. Regarding charter school autonomy, cluster 2 had a mean of zero indicating that six states required charter schools to follow the same governance laws as traditional public schools. These states also engaged in the same hiring practices as traditional public schools. Cluster 1 and cluster 3 reflected high levels of charter school autonomy, both with means of $2.5(\mathrm{SD}=0.76)$ and $2.73(\mathrm{SD}=0.55)$, respectively.

School funding equity laws stipulated that charter schools were allocated the same per-student and facility dollars as traditional public schools. Cluster 2 had lower levels of funding equity with a mean of 0.21 (SD =0.51), while cluster 1 had the highest mean for charter school funding equity at $1.14(\mathrm{SD}=0.54)$. Cluster 3 ranked just below cluster 1 , with a mean of $1.09(\mathrm{SD}=0.61)$.

Charter school growth supports charter schools' proliferation by allowing multiple charter authorizers, not capping the number of charter schools permitted to operate in the state and allowing rejected charter applications to be appealed. Cluster 2 had the lowest mean score for charter school growth, 0.57 (SD = 0.85). Cluster 1 resembled cluster 2 with a low mean of 0.79 (SD = 0.43). Cluster three had the highest level of charge school growth with a mean of $2.55(\mathrm{SD}=0.51)$.

The cluster analysis separated the states into three unique clusters. Cluster 1 states had high mean scores in charter school autonomy and equal funding, but lower mean scores in charter school growth. Cluster 3 states had the highest or second highest mean scores in autonomy, funding equity and growth. Cluster 2 states had the lowest mean scores for autonomy, funding equity and growth.

In sum, cluster 1 states had charter school laws that supported autonomy and funding equity, but not growth. Cluster 1 was described as "Support-with-Limited-
Growth", due to the growth mean being low and all other means being relatively high. States in cluster 2 had charter school laws that generally do not support autonomy, funding equity, or growth. Cluster 2 was described as "Limited-Support," because it contained lowest mean scores in all the charter school legislative areas, thereby limiting charter school support. States in cluster 3, the "allsupportive" cluster, had the highest or second highest mean scores for funding, equity and growth.

Although three descriptively unique clusters emerged, a test for statistical differences was performed. The authors conducted an ANOVA on the states in each cluster to test statistical differences among the autonomy, funding equity and growth means. The ANOVA results appear in Table 3.

The ANOVA revealed significant differences in the charter school autonomy means across the three state clusters $[\mathrm{F}(2,47)=119.73, \mathrm{p}=0.00]$. Similarly, a significant differences was found in the charter school equity funding means $[\mathrm{F}(2,47)=12.2, \mathrm{p}=0.00]$ and the charter school growth means $[\mathrm{F}(2,47)=58.97, \mathrm{p}=0.00]$. The ANOVA results demonstrated that the clusters formed from the analysis were statistically significant, signifying three state clusters with unique charter school law characteristics.

A Tukey Honest Significance Difference (HSD) posthoc test, shown in Table 4, identified where the differences lie among the groups (Greene, 2000). Significant differences were not always observed between pairs of cluster for every variable, although the overall cluster analysis was significant. Regarding autonomy, the support-with-limited-growth cluster $(\mathrm{M}=2.50, \mathrm{SD}=$ $0.76)$ and the all-supportive cluster $(\mathrm{M}=2.73, \mathrm{SD}=0.55)$ were not statistically different from each other $(p=0.45)$, but differed from the limited-support cluster $(\mathrm{M}=0.00$, $\mathrm{SD}=0.00, \mathrm{p}<0.05)$. Results for funding equity showed that the support-with-limited-growth cluster $(\mathrm{M}=1.14$, $\mathrm{SD}=0.54)$ and the all-supportive cluster $(\mathrm{M}=1.09, \mathrm{SD}=$ $0.61)$ did not statistically differ $(p=0.96)$. However, the support-with-limited-growth cluster and the allsupportive cluster were statistically different from the limited support cluster $(\mathrm{M}=0.21, \mathrm{SD}=0.51, \mathrm{p}<0.05)$. Results for charter school growth indicated the support-withlimited-growth cluster $(\mathrm{M}=0.79, \mathrm{SD}=0.43)$ was not statistically distinct from the limited-support cluster $(\mathrm{M}=$ $0.57, \mathrm{SD}=0.85, \mathrm{p}=0.62$ ). However, both the support-withlimited-growth cluster and the limited-support cluster were statistically different from the all-supportive cluster $(\mathrm{M}=$ 2.55, $\mathrm{SD}=0.51, \mathrm{p}<0.05)$.

Findings from the Tukey HSD post-hoc test supported the descriptive cluster groupings. The support-withlimited-growth cluster and the all-supportive cluster behaved similarly with charter school laws supporting autonomy and funding equity. The limited-support cluster differed from the other two clusters by not having laws that facilitated charter school autonomy and funding 
equity. The support-with-limited-growth cluster and the all-supportive cluster differed in terms of growth.

The second analysis described the composite variables and used chi-square tests to determine whether the composite variables differed across the three clusters developed in the first analysis. The first index variable was autonomy, which included the composite variables of state autonomy, local/district autonomy and teacher hiring autonomy.

Table 2: State charter school policy characteristics

\begin{tabular}{lcc}
\hline & $\mathrm{N}$ & $\%$ \\
\hline Autonomy (complete) & 33 & 67.7 \\
State & 34 & 68.6 \\
Local/district & 28 & 56.9 \\
Teacher hiring & & 27.5 \\
Funding same as public school & 13 & 58.8 \\
Student & 29 & 50.0 \\
Facility & & 49.0 \\
Growth & 25 & 50.0 \\
No Cap & 24 & \\
Appeal process & 25 & \\
Multiple authorizers & &
\end{tabular}

Note: All states $(\mathrm{N}=50)$, District of Columbia not included

Table 3: Charter school index variables cluster analysis ANOVA

\begin{tabular}{|c|c|c|c|c|c|}
\hline Charter school index variables & $d f$ & SS & $M S$ & $F$ & $P$ \\
\hline \multicolumn{6}{|l|}{ Autonomy } \\
\hline Between groups & 2.00 & 70.64 & 35.32 & 1119.73 & .00 \\
\hline Within groups & 47.00 & 13.86 & 0.30 & -- & -- \\
\hline Total & 49.00 & 85.54 & -- & -- & -- \\
\hline \multicolumn{6}{|l|}{ Funding equity } \\
\hline Between groups & 2.00 & 8.13 & 4.07 & 12.02 & .00 \\
\hline Within groups & 47.00 & 15.89 & 0.34 & -- & -- \\
\hline Total & 49.00 & 24.02 & -- & -- & -- \\
\hline \multicolumn{6}{|l|}{ Growth } \\
\hline Between groups & 2.00 & 43.26 & 21.63 & 58.97 & .00 \\
\hline Within groups & 47.00 & 17.24 & 0.37 & -- & -- \\
\hline Total & 49.00 & 60.50 & -- & -- & -- \\
\hline
\end{tabular}

Note: All states $(\mathrm{N}=50)$, District of Columbia not included

Table 4: Tukey post-hoc test for ANOVA of charter school index variables.

\begin{tabular}{|c|c|c|c|c|c|}
\hline Charter school index variables & Primary grp & Comparison grp & Mean difference & Std. error & Sig. \\
\hline \multirow{6}{*}{ Autonomy } & 1 & 2 & $2.500^{*}$ & 0.205 & 0 \\
\hline & & 3 & -0.227 & 0.186 & 0.445 \\
\hline & 2 & 1 & $-2.500 *$ & 0.205 & 0 \\
\hline & & 3 & -2.727 & 0.186 & 0 \\
\hline & 3 & 1 & 0.227 & 0.186 & 0.445 \\
\hline & & 2 & $2.727 *$ & 0.186 & 0 \\
\hline \multirow[t]{6}{*}{ Funding equity } & 1 & 2 & $0.929 *$ & 0.22 & 0 \\
\hline & & 3 & 0.052 & 1.99 & 0.963 \\
\hline & 2 & 1 & $-.929 *$ & 0.22 & 0 \\
\hline & & 3 & $-0.877 *$ & 0.199 & 0 \\
\hline & 3 & 1 & -0.052 & 0.199 & 0.963 \\
\hline & & 2 & $0.877 *$ & 0.199 & 0 \\
\hline \multirow[t]{6}{*}{ Growth } & 1 & 2 & 0.214 & 0.229 & 0.62 \\
\hline & & 3 & $-1.760 *$ & 0.207 & 0 \\
\hline & 2 & 1 & -0.214 & 0.229 & 0.62 \\
\hline & & 3 & $-1.974 *$ & 0.207 & 0 \\
\hline & 3 & 1 & $1.760 *$ & 0.207 & 0 \\
\hline & & 2 & $1.974 *$ & 0.207 & 0 \\
\hline
\end{tabular}

*The mean difference is significant at the 0.05 level 
Table 5: Frequencies and Chi-Square Tests for Charter School Composite Variables

\begin{tabular}{|c|c|c|c|c|c|c|c|c|}
\hline & \multicolumn{2}{|c|}{$\begin{array}{l}\text { Limited- } \\
\text { Support }\end{array}$} & \multicolumn{2}{|c|}{$\begin{array}{l}\text { Support-with- } \\
\text { Limited-Growth }\end{array}$} & \multicolumn{2}{|c|}{ All Supportive } & \multirow[b]{2}{*}{ Chi-Square } & \multirow[b]{2}{*}{ DF } \\
\hline & $\mathrm{N}$ & $\%$ & $\mathrm{~N}$ & $\%$ & $\mathrm{~N}$ & $\%$ & & \\
\hline \multicolumn{9}{|l|}{ Autonomy (complete) } \\
\hline State & 0 & 0 & 13 & 93 & 20 & 91 & $37.76^{*}$ & 2 \\
\hline Local/district & 0 & 0 & 13 & 93 & 21 & 96 & $41.34 *$ & 2 \\
\hline Teacher hiring & 0 & 0 & 9 & 64 & 19 & 86 & $26.44 *$ & 2 \\
\hline \multicolumn{9}{|c|}{ Funding same as public school } \\
\hline Student & 1 & 7 & 7 & 50 & 6 & 27 & $6.38 *$ & 2 \\
\hline Facility & 2 & 14 & 9 & 64 & 18 & 82 & $16.33^{*}$ & 2 \\
\hline \multicolumn{9}{|l|}{ Growth } \\
\hline No Cap & 5 & 36 & 3 & 21 & 18 & 82 & 14.57 & 2 \\
\hline Appeal process & 3 & 21 & 2 & 14 & 19 & 86 & 23.3 & 2 \\
\hline Multiple authorizers & 0 & 0 & 6 & 43 & 19 & 86 & 25.92 & 2 \\
\hline
\end{tabular}

Note: All states $(\mathrm{N}=50)$, district of columbia not included. $*=\mathrm{p}<0.05$

Second, the index variable of funding equity was comprised of student and facility funding. The third index variable, growth, included the composite variables of no cap on charter schools, appeal process allowed and multiple authorizers allowed. Table 5 displays the frequencies, percentages and chi-square tests for each composite variable.

Autonomy was not observed in the limited-support cluster for the composite variables of state, local and teacher autonomy. States in this cluster either had not adopted charter school legislation or had not granted any autonomy to charter schools. The support-withlimited-growth cluster demonstrated a high degree of autonomy for state (93\%), local/district (93\%) and teacher hiring (64\%). Similarly, the all-supportive cluster showed a high percentage of states with autonomy from the state (91\%) and local/district (96\%) and well as teacher hiring autonomy (86\%).

The chi-square test for the autonomy composite variables revealed significant differences across state clusters for the composite variables state autonomy $\mathrm{X}^{2}(2$, $\mathrm{N}=50)=37.76, \mathrm{p}>0.05$, local/district autonomy $\mathrm{X}^{2}(2, \mathrm{~N}$ $=50)=41.34, \mathrm{p}>0.05$ and teacher autonomy $\mathrm{X}^{2}(2, \mathrm{~N}=$ $50)=26.44, p>0.05$. The chi-square tests showed that frequencies of the composite variables in the autonomy index were significantly different.

The limited-support cluster had the lowest percentage of states with equal facility funding (14\%) and equal student funding (7\%), whereas the support-with-limitedgrowth cluster had the highest percentage of states with equal student funding $(50 \%)$ and ranked second highest for equal facility funding $(64 \%)$. The all-supportive cluster contained a lower percentage of states with equal student funding $(27 \%)$, but had the most states with equal facility funding (82\%). A pattern emerged among the funding composite variables revealing that most states in all three clusters allocated less funding for charter schools than traditional public schools. However, states in the all-supportive and support-with-limited-growth clusters received more facility funding than the limited-support cluster.

Chi-square tests for the funding equity composite variables demonstrated an overall significant difference among the state clusters. Differences emerged in the clusters for the composite variables: Student funding $\mathrm{X}^{2}$ $(2, \mathrm{~N}=50)=37.76, \mathrm{p}>0.05$, local/district autonomy $\mathrm{X}^{2}(2$, $\mathrm{N}=50)=41.34, \mathrm{p}>0.05$ and teacher autonomy $\mathrm{X}^{2}(2, \mathrm{~N}=$ 50) $=26.44, \mathrm{p}>0.05$.

In the limited support cluster, $36 \%$ of states did not have a cap on the number of charter schools created in a one-year period, while $21 \%$ percent of states allowed an appeals process following the denial of charter proposals. No states in this cluster allowed multiple authorizers. The support-with-limited-growth cluster had the lowest percentage of states without a cap charter schools (36\%). Fourteen percent of states in this cluster allowed an appeal and $43 \%$ allowed multiple authorizers. The all-supportive cluster had the highest percentage of states with no annual cap on charter schools $(82 \%)$. About $86 \%$ of states in this cluster allowed an appeals process and $86 \%$ of states allowed multiple authorizers.

The chi-square test illustrated significant cluster differences for all of the growth composite variables. These variables included no cap on charter schools $\mathrm{X}^{2}(2$, $\mathrm{N}=50)=14.57, \mathrm{p}>0.05$, appeals process allowed $\mathrm{X}^{2}(2$, $\mathrm{N}=50)=23.30, \mathrm{p}>0.05$ and multiple authorizers allowed $\mathrm{X}^{2}(2, \mathrm{~N}=50)=25.92, \mathrm{p}>0.05$. 


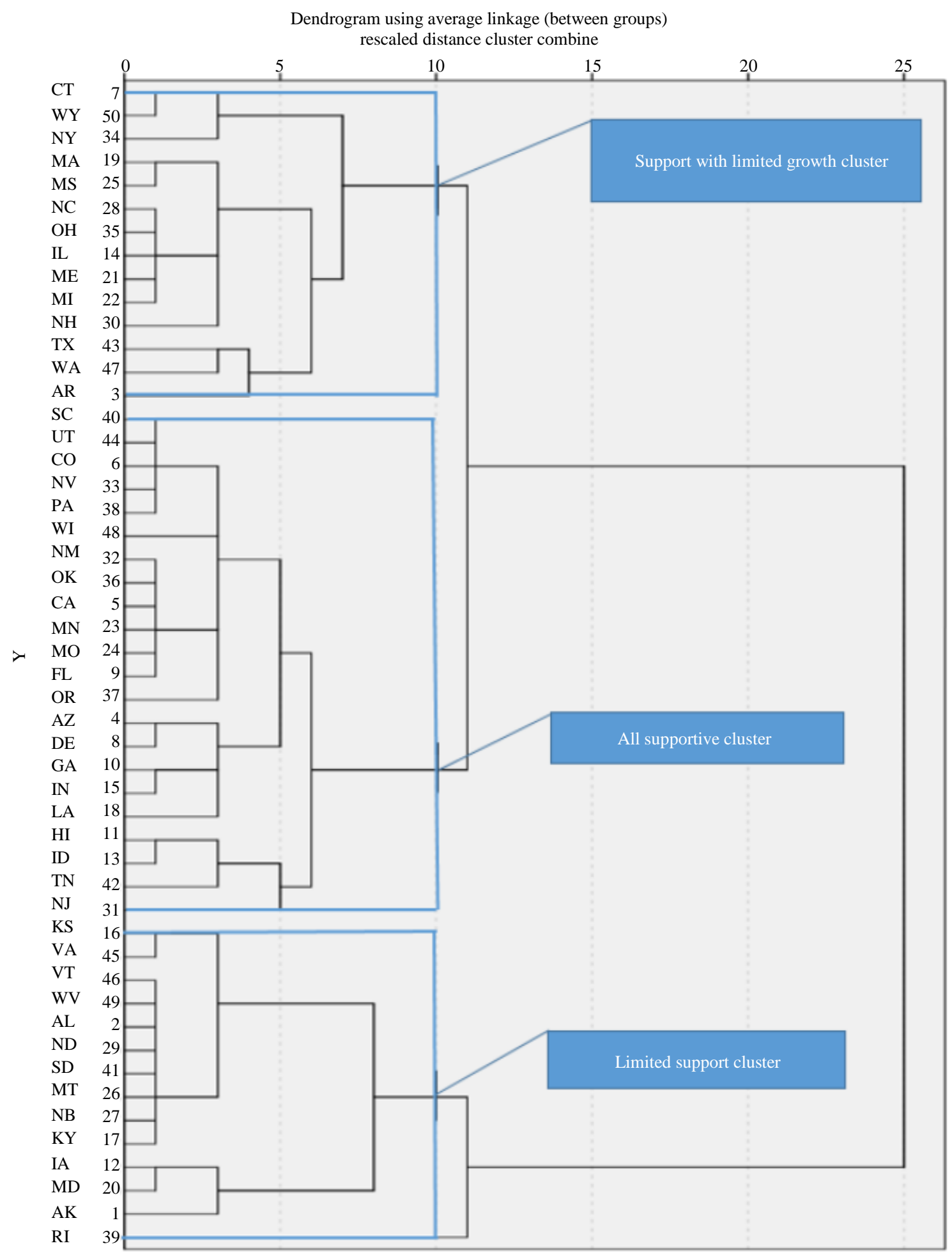

Fig. 1: The authors ran a cluster analysis with and without states that do not have charter schools. The clusters were identical in both analyses, aside from the eight states without charter school laws (WV, KY, AL, SD, VT, NB, ND and MT). Thus, the authors kept the cluster solutions that included states without charter school laws. Cluster 1 included the following 14 states: MA, MS, MI, OH, NC, IL, ME, WA, NH, WY, CT, TX, NY, AR. Cluster two included the following 14 states: WV, KY, AL, SD, VT, NB, ND, MT, KS, VA, IA, MD, AK, RI. Cluster was made up of 22 states that included: ID, HI, TN, LA, UT, NV, PA, SC, CO, CA, FL, NM, OK, MN, MO, AZ, DE, GA, IN, OR, WI, NJ 


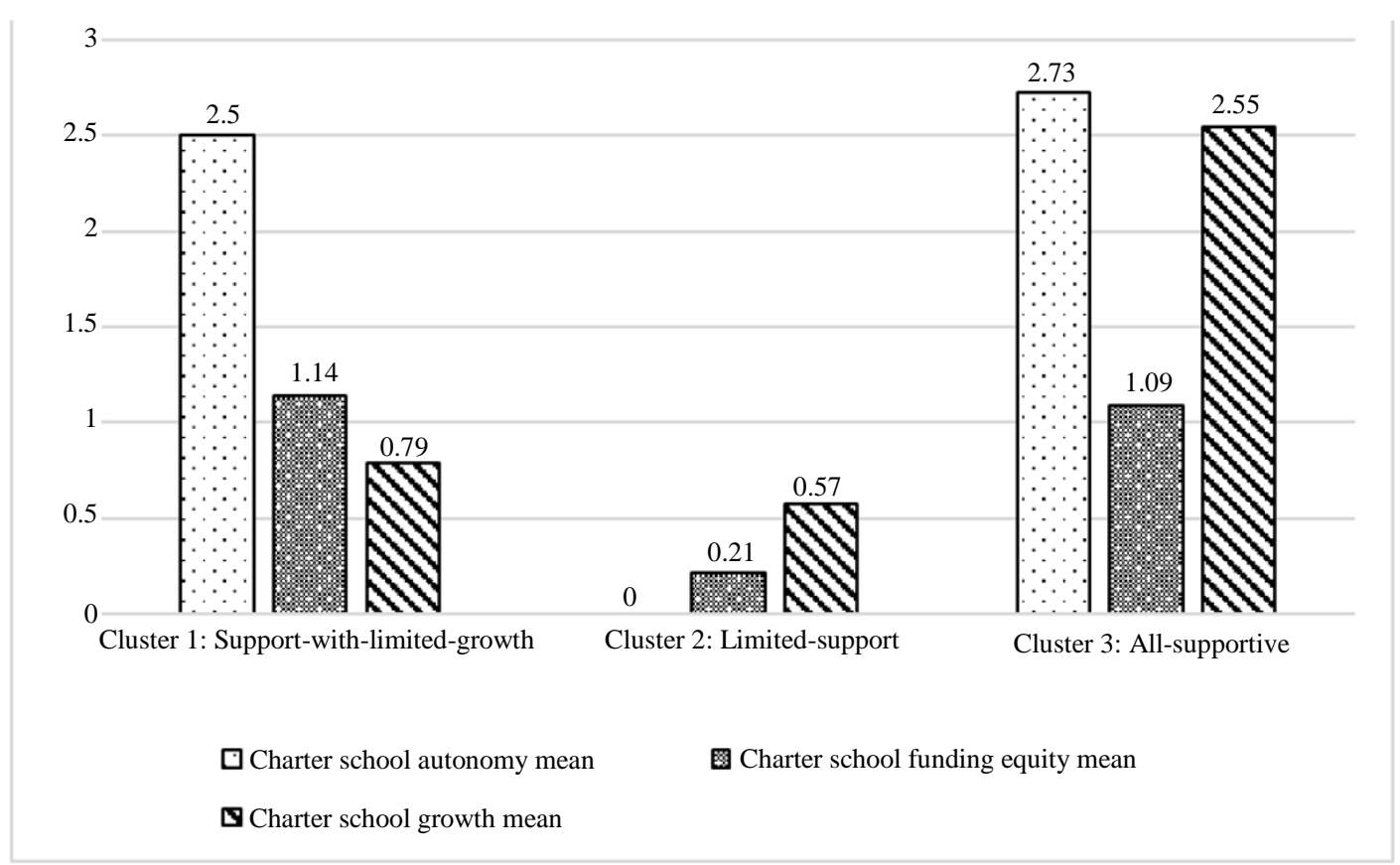

Fig. 2: State charter school policy cluster means

\section{Discussion}

This study identified characteristics of charter school laws across states and grouped states into statistically distinct clusters. Findings indicated that states did not uniformly adopt particular provisions of charter school laws such as autonomy, funding and growth. The cluster analysis revealed three clusters that the authors described as the support-with-limited-growth cluster of 14 states (cluster 1), limited-support cluster of 14 states (cluster 2) and the all-supportive cluster of 22 states (cluster 3). More specifically, states can adopt charter school laws in such a way that supports and enables the proliferation of new charter schools, which was seen in the all-supportive cluster. States can also adopt charter school legislation in a way that supports the existing charter schools but limits the number of new charter schools each year, as was observed in the support-with-limited-growth cluster. Other states allow charter schools but limit their autonomy, funding equity and growth. States in the limited-support cluster allow charter schools to exist in such a limited way that these schools may not be much different traditional public schools.

Prior research on charter school adoption legislation has focused on predicting whether states adopt a policy or not (Cohen-Vogel and Ingle, 2007; Renzulli and Roscigno, 2005; Wong and Langevin, 2007). Although important, this dichotomy may not adequately represent the full landscape of charter school policy because states do not adopt uniform policies. This study provides future researchers a tool to classify and study differences in the adoption and effectiveness of charter school policies. For example, future research could determine if (Renzulli and Roscigno, 2005) finding that adjacency predicts adoption repeats itself when predicting cluster membership. Using the current findings, researchers could examine the extent to which state characteristics such as standardized tests, political party, or the prominence of private schools in a state may predict variations in charter law provisions and the state's cluster classification, providing a valuable extension of (Wong and Langevin, 2007).

Similarly, most of the literature on charter school effectiveness has not accounted for charter school law characteristics within each state (Bettinger, 2005; Cohodes, 2016; Eberts and Hollenbeck, 2002; Gronberg and Jansen, 2001; Hanushek et al., 2002; Lubienski, 2003; Ni and Rorrer, 2012; Solmon et al., 2001). It is possible that the law characteristics within a state can influence school performance. Some state laws provide charter schools with different rates of perstudent funding than traditional public schools and research has shown that schools with financial disadvantages will not perform as well as peer schools without those disadvantages (Eberts and Hollenbeck, 2002). On the other hand, state laws can provide more autonomy to charter schools, which may lead to innovation in classroom and build on best practices. Traditional public schools without that level of autonomy may require bureaucratic processes to pursue innovative instructional changes (Cohodes, 2016). 


\section{Limitations}

This study intended to provide a nuanced approach to better understanding the state-level variation of charter school laws in the U.S. This study did not attempt to use prediction models or determine cause and effect (Johnson, 1953). Although the findings do not further causal arguments, this study should be viewed as a pre-cursor to future research that predicts the adoption of specific charter school law provisions and assesses their influence on charter school effectiveness.

Limitations should also be noted for the cluster analysis. The potential for arbitrary cluster groupings based on insensitivity to data differences may be a limitation due to not having a variety of categories for a small number of cases. Furthermore, Rhode Island may have been arbitrarily placed in the limited-support cluster because the four-cluster solution created a cluster containing only Rhode Island. To reduce this possibility, the authors conducted ANOVAs to reveal if significant differences existed between the index variables.

\section{Conclusion}

This study adds to the literature by describing and categorizing variations in charter school legislation among U.S. states. The findings illuminate complexities in how charter school laws differ from state to state regarding autonomy, funding equity and growth. This framework provides a mechanism for future studies to assess the impact of variations in charter school laws across states.

Charter schools that are dynamic in their curriculum design and instructional strategies can theoretically improve academic performance (Cohodes, 2016). However, their autonomy may lead to poor decisions and hiring less qualified faculty. Researchers must account for different policy environments when comparing charter schools to traditional public schools. Work that does not account for this legislative context may misrepresent the effectiveness of either school type. Future research should continue to compare the performance of charter schools to traditional public schools while couching these comparable results in the context of the state's legislative environment and then compare results across states.

\section{Author's Contributions}

William Dabney: Designed the research plan, organized the study and contributed to the writing of the manuscript.

Bret Blackmon: Organized and contributed to the writing of the manuscript. Assisted in the development of the study.

Michelle M. Livermore: Assisted with developing the study design and statistical analysis. contributed to the writing of the manuscript.

\section{Ethics}

The authors confirm that there is no conflict of interest nor funding to declare. This manuscript is not being considered for publication elsewhere. The researchers received IRB approval from Louisiana State University.

\section{References}

Berends, M. (2015). Sociology and school choice: What we know after two decades of charter schools. Annual Review of Sociology, 41, 159-180. https://www.annualreviews.org/doi/full/10.1146/ann urev-soc-073014-112340

Bettinger, E. P. (2005). The effect of charter schools on charter students and public schools. Economics of Education Review, 24(2), 133-147. https://www.sciencedirect.com/science/article/abs/pi i/S0272775704000779

Buddin, R., \& Zimmer, R. (2005). Student achievement in charter schools: A complex picture. Journal of Policy Analysis and Management, 24(2), 351371.

Center for Education Reform. (2014). National charter schools and enrollment statistics. Washington, DC: Center for Education Reform. https://www.edreform.com/2014/03/2014-charterschool-law-rankings-scorecard/.

Cohen-Vogel, L., \& Ingle, W. K. (2007). When neighbours matter most: Innovation, diffusion and state policy adoption in tertiary education. Journal of Education $\quad$ Policy, 22(3), 241-262. https://www.tandfonline.com/doi/abs/10.1080/0268 0930701269152

Cohodes, S. R. (2016). Teaching to the student: Charter school effectiveness in spite of perverse incentives. Education Finance and Policy, 11(1), 1-42. https://direct.mit.edu/edfp/article/11/1/1/10247/Teac hing-to-the-Student-Charter-School

Eberts, R. W., \& Hollenbeck, K. (2002). Impact of charter school attendance on student achievement in Michigan. https://papers.ssrn.com/sol3/papers.cfm?abstract_id $=316562$

Everitt, B. S., Landau, S., Leese, M., \& Stahl, D. (2011). Cluster analysis 5 th ed.

Greene, W. H. (2000). Econometric analysis 4th edition. International edition, New Jersey: Prentice Hall, 201-215.

Gronberg, T. J., \& Jansen, D. W. (2001). Navigating newly chartered waters: An analysis of Texas charter school performance. Texas Public Policy Foundation. https://www.texaspolicy.com/content/detail/navigati ng-newly-chartered-waters 
Hanushek, E. A., Kain, J. F., Rivkin, S. G., \& Branch, G. (2002). The impact of charter schools on academic achievement.

https://conference.nber.org/confer/2002/hiedf02/KA IN.pdf

Henig, J. R. (2008). Spin cycle: How research gets used in policy debates--The case of charter schools. Russell Sage Foundation.

Jacob, B., \& Ludwig, J. (2008). Improving educational outcomes for poor children (No. w14550). National Bureau of Economic Research. https://www.nber.org/papers/w14550

Johnson, L. H. (1953). Limitations of the descriptive method. The Phi Delta Kappan, 34(6), 241-245. https://www.jstor.org/stable/20332351?seq=1

Lubienski, C. (2003). Innovation in education markets: Theory and evidence on the impact of competition and choice in charter schools. American Educational Research Journal, 40(2), 395-443. https://journals.sagepub.com/doi/abs/10.3102/00028 312040002395

Mintrom, M., \& Vergari, S. (1998). Policy networks and innovation diffusion: The case of state education reforms. The Journal of Politics, 60(1), 126-148. https://www.journals.uchicago.edu/doi/abs/10.2307/ 2648004

NCES. (2017a). "The Nation's Report Card, Math 2017: National Assessment of Educational Progress at Grades 4 and 8." U.S. National Center for Education Statistics.

https://www.nationsreportcard.gov/math_2017/natio n/achievement?grade $=4$

NCES. (2017b). "The Nation's Report Card, Reading 2017: National Assessment of Educational Progress at Grades 4 and 8." U.S. Department of Education, Institute of Education Sciences. National Center for Education Statistics. https://www.nationsreportcard.gov/reading_2017/na tion/achievement? grade $=4$
Neal, D. A., \& Schanzenbach. D. (2008). Left behind by design: Proficiency counts and test-based Accountability National Journal of Economic Research, 118, 72-92. https://www.sesp.northwestern.edu/docs/publication s/1128718468551ec75b5f701.pdf

Ni, Y., \& Rorrer, A. K. (2012). Twice considered: Charter schools and student achievement in Utah. Economics of Education Review, 31(5), 835-849. https://www.sciencedirect.com/science/article/abs/pi i/S0272775712000714

Renzulli, L. A., \& Roscigno, V. J. (2005). Charter school policy, implementation and diffusion across the United States. Sociology of Education, 78(4), 344-366.

https://journals.sagepub.com/doi/abs/10.1177/00380 4070507800404

Shakeel, M. D., \& Peterson, P. E. (2020). Charter schools show steeper upward trend in student achievement than district schools. Education Next, 21 (1) https://www.educationnext.org/charter-schoolsshow-steeper-upward-trend-student-achievementfirst-nationwide-study/

Solmon, L., Paark, K., \& Garcia, D. (2001). Does charter school attendance improve test scores? The Arizona Results.

USDE. (2014). Twenty-five years of progress in education children with disabilities through IDEA. US Department of Education. http://www.ed.gov/

Washington, D. C. (2014). Center for Education Reform. https://www.edreform.com/2014/03/2014-charterschool-law-rankings-scorecard/

Wong, K. K., \& Langevin, W. E. (2007). Policy expansion of school choice in the American states. Peabody Journal of Education, 82(2-3), 440-472. https://www.tandfonline.com/doi/abs/10.1080/0161 9560701313085 